\title{
Pengaruh Budaya Organisasi Terhadap Efektivitas Kerja Pegawai Kantor Pelayanan Pajak
}

\author{
${ }^{1}$ Bernit Hamonangan Pakpahan, ${ }^{2}$ Lidia Kandau Bangun, ${ }^{3}$ Ida Liana Nasution, ${ }^{4}$ Andri Muharwan \\ ${ }^{1-4}$ Program Magister Manajemen, Fakultas Ekonomi, Universitas Islam Sumatera Utara
}

\author{
Article history \\ Received: 12 Nov 2020 \\ Revised: 11 Dec 2020 \\ Accepted: 30 Dec 2020 \\ *Corresponding Author: \\ Benit Hamonangan \\ Pakpahan, Program Studi \\ Magister Manajemen, \\ Fakultas Ekonomi, \\ Universitas Islam Sumatera \\ Utara \\ Email: \\ bernithamonanganpak@gmai \\ $\underline{1 . c o m}$
}

\begin{abstract}
Abstrak: Penting untuk mengetahui dan menganalisis pengaruh budaya organisasi terhadap efektivitas kerja pegawai Kantor Pelayanan Pajak Pratama Medan Kota. Sampel yang diambil adalah berjumlah 54 orang. Dalam penelitian ini peneliti menyebarkan kuesioner pada 54 orang pegawai di antor Pelayanan Pajak Pratama Medan. Hasil analisis data maka ditemukan bahwa Budaya organisasi berpengaruh positif dan signifikan terhadap kinerja pegawai Kantor Pelayanan Pajak Pratama Medan Kota, hal ini didukung hasilanalisisthitung $>$ t-tabel $(3,603>2,009)$ pada $n=54$ pada taraf sifgifikansi $95 \%$.
\end{abstract}

Kata Kunci : Pengaruh Budaya, Organisasi, Efektivitas Kerja, Pelayanan Pajak

\section{PENDAHULUAN}

Masalah budaya itu sendiri merupakan hal yang esensial bagi suatu organisasi, karena akan selalu berhubungan dengan kehidupan yang ada dalam organisasi. Koesmono (2009) menyebutkan Budaya organisasi merupakan falsafah, ideologi, nilai-nilai, anggapan, keyakinan, harapan, sikap dan norma-norma yang dimiliki secara bersama serta mengikat dalam suatu komunitas tertentu. Secara spesifik budaya dalam organisasi akan ditentukan oleh kondisi kerja tim, kepemimpinan dan karakteristik organisasi serta proses administrasi yang berlaku.

Selanjutnya Sarplin (2009) menyatakan bahwa budaya organisasi merupakan suatu sistem nilai, kepercayaan dan kebiasaan dalam suatu organisasi yang saling berinteraksi dengan struktur sistem formalnya untuk menghasilkan norma-norma perilaku organisasi. Budaya organisasi sebagai suatu pola dari asumsi-asumsi dasar yang ditemukan, diciptakan atau dikembangkan oleh suatu kelompok tertentu dengan maksud agar organisasi belajar mengatasi atau menanggulangi masalah-masalahnya yang timbul akibat adaptasi eksternal dan integrasi internal yang sudah berjalan dengan cukup baik, sehingga perlu diajarkan kepada anggota-anggota baru sebagai cara yang benar untuk memahami, memikirkan dan merasakan berkenaan dengan masalah-masalah tersebut (Schein, 2008).

Menurut Lok and Crawford (2008) budaya organisasi berpengaruh signifikan terhadap hasil kerja. Agar tugas pegawai dapat terlaksana dan mencapai tujuannya seluruh anggota organisasi harus memahami budaya organisasi. Oleh sebab itu, pegawai harus memahami budaya organisasi, sehingga pegawai dapat melakukan tugasnya masing-masing dengan baik. Untuk mencapai tujuan organisai anggota organisasi pada setiap bagian harus nenerapkan budaya organisasi, kepemimpinan yang demokratis dan memiliki komitmen yang tinggi agar dalam menjalankan visi dan misi sesuai yang ditetapkan sehingga organisasi 
memiliki kinerja yang tinggi yang pada akhirnya terlaksana pembangunan sebagaimana yang telah ditetapkan.

Budaya organisasi belum begitu melekat pada diri pegawai dimana perilaku pegawai belum sesuai budaya yang dianut oleh Kantor Pelayanan Pajak Pratama Medan Kota sehingga efektivits kerja pegawai agak sulit dicapai, kepemimpinan di Kantor Pelayanan Pajak Pratama Medan Kota juga belum begitu menunjukkan gaya yang demokratis sehingga pegawai seperti tidak memiliki pemimpin yang mengawasi dan menggerakkannya. Komitmen pegawai juga belum maksimal sehingga pegawai tidak dapat melaksanakan pekerjaan yang secara efektif.

Komaruddin (2007) efektivitas adalah : "Suatu keadaan dalam mencapai tujuan manajemen yang efektif perlu disertai dengan manajemen yang efisien. Menunjukkan tingkat keberhasilan yang efisien. Tercapainya tujuan mungkin hanya dapat dilakukan dengan penghamburan dana. Oleh karena itu manajemen tidak boleh diukur dengan efektivitas juga diperlukan efisiensi". Selanjutnya Sarwoto (2008) menyatakan bahwa berhasil guna atau efektif kerja adalah pelayanan yang baik corak dan mutunya benar-benar sesuai kebutuhan dalam pencapaian tujuan organisasi.

\section{METODE PENELITIAN}

\section{Uji Heterokedastisitas}

Uji heterokedastisitas bertujuan untuk menguji apakah dalam model regresi terjadi ketidaksamaan varians dari residual satu pengamatan ke pengamatan yang lain. Analisis grafik dengan melihat grafik plot, yaitu dengan melihat ada tidaknya pola tertentu pada grafik scatterplot, dimana sumbu Y yang telah diprediksi dan sumbu X adalah residual (Y prediksi Y sesungguhnya).

\section{Uji Normalitas}

Uji anormalitas dilakukan untuk melihat apakah dalam model rergreasi variabel terikat dan variabel bebas keduanya mempunyai distribusi normal atau tidak. Model regresi yang baik adalah model regresi yang berdistribusi normal. Untuk melihat data berdistribusi normal dapat diketahui dari histogram dan grafik penyebaran titik di sekitar garis diagonal dn mengikuti arah garis diagonal.

Setelah dilakukan uji asumsi klasik dan memenuhi syarat untuk menggunakan uji regresi berganda yakni Model penduga Regresi Linier Berganda, dengan metode "OLS" (Ordinary Least Square) dengan matematik dapat dituliskan persamaan sebagai berikut:

1) $Y=a+b_{1} X_{1}+b_{2} X_{2}+b_{3} X_{3}+e \quad$ (Sudjana, 2011:324)

\section{Uji t (Parsial)}

Untuk mengetahui pengaruh variabel bebas terhadap variabel terikat secara parsial dapat di uji melalui uji t yaitu :

$$
t_{\text {hitung }}=\frac{b_{1}}{s b_{1}}
$$




\section{Uji F}

Untuk mengetahui variabel bebas berpengaruh secara serempak terhadap variabel terikat maka digunakan Uji F yaitu $: \mathrm{F}=\frac{J K_{R E G} k}{J K_{R E G}(n-k-1)}$

Uji $\mathrm{F}$ ini berdistribusi $\mathrm{F}$ dengan dk pembilang $=\mathrm{k}$

dk penyebut $=(n-k-1)$

\section{Uji Determinasi}

Untuk mengetahui besar pengaruh variabel bebas terhadap variabel terikat dapat dilihat dari koefisien determinasi berganda $\left(\mathrm{R}^{2}\right)$, dimana $\mathrm{D}=\mathrm{R}^{2} \times 100 \%$. Untuk mempermudah analisis data digunakan komputer dengan memakai program Statistical Product and Service Solution (SPSS) versi 24.0.

\section{PEMBAHASAN}

\section{Statistik Deskriptif}

Dari data yang diperoleh untuk variabel budaya organsisasi dan efektivitas kerja pegawai dapat dilihat gambaran hasil penelitian statistik deskriptif secara umum berikut ini :

Tabel 1. Statistik Deskriptif

\begin{tabular}{|c|c|c|c|c|c|c|c|}
\hline \multirow{2}{*}{ Variabel } & \multirow{2}{*}{ Instrumen } & \multicolumn{6}{|c|}{ Frekwensi (Persentase) } \\
\hline & & 5 & 4 & 3 & 2 & 1 & Total \\
\hline & 1. EKP1 & 25,9 & 74,1 & 0 & 0 & 0 & 100 \\
\hline & 2. EKP2 & 40,7 & 59,3 & 0 & 0 & 0 & 100 \\
\hline & 3. EKP3 & 20,4 & 64,8 & 14,8 & 0 & 0 & 100 \\
\hline & 4. EKP4 & 35,2 & 64,8 & 0 & 0 & 0 & 100 \\
\hline Efektivitas Kerja & 5. EKP5 & 35,2 & 63,0 & 1,9 & 0 & 0 & 100 \\
\hline \multirow[t]{8}{*}{ Pegawai (Y) } & 6. EKP6 & 1,9 & 70,4 & 27,8 & 0 & 0 & 100 \\
\hline & 7. EKP7 & 1,9 & 57,4 & 40,7 & 0 & 0 & 100 \\
\hline & 8. EKP8 & 0 & 77,8 & 22,2 & 0 & 0 & 100 \\
\hline & 9. EKP9 & 0 & 68,5 & 29,6 & 1,9 & 0 & 100 \\
\hline & 10. EKP10 & 0 & 53,7 & 46,3 & 0 & 0 & 100 \\
\hline & 1. $\mathrm{BO} 1$ & 20,4 & 74,1 & 5,6 & 0 & 0 & 100 \\
\hline & 2. $\mathrm{BO} 2$ & 16,7 & 64,8 & 14,8 & 3,7 & 0 & 100 \\
\hline & 3. $\mathrm{BO} 3$ & 46,3 & 53,7 & 0 & 0 & 0 & 100 \\
\hline \multirow{5}{*}{$\begin{array}{l}\text { Budaya Organisasi } \\
\text { (X1) }\end{array}$} & 4. $\mathrm{BO} 4$ & 46,3 & 53,7 & 0 & 0 & 0 & 100 \\
\hline & 5. $\mathrm{BO} 5$ & 50,0 & 50,0 & 0 & 0 & 0 & 100 \\
\hline & 6. BO6 & 9,3 & 61,1 & 29,6 & 0 & 0 & 100 \\
\hline & 7. $\mathrm{BO} 7$ & 9,3 & 51,9 & 33,3 & 3,7 & 1,9 & 100 \\
\hline & 8. $\mathrm{BO} 8$ & 9,3 & 55,6 & 31,5 & 3,7 & 0 & 100 \\
\hline
\end{tabular}




\begin{tabular}{llllllll}
\hline 9. & BO9 & 5,6 & 50,0 & 44,4 & 0 & 0 & 100 \\
10. BO10 & 9,3 & 57,4 & 31,5 & 1,9 & 0 & 100 \\
\hline
\end{tabular}

Sumber: Hasil Penelitian 2020

Berdasarkan tabel di atas dapat disimpulkan sebagai berikut :

1. Jawaban responden mengenai efektivitas adalah pengukuran, dalam arti pencapaian tujuan yang telah ditentukan sebelumnya sebanyak 25,9\% menjawab sangat setuju, setuju sebanyak $74,1 \%$.

2. Jawaban responden mengenai dalam mencapai efektivitas kerjaumumnya dipakai empat macam pertimbangan yaitu : "pertimbangan ekonomi, pertimbangan fisiologi, pertimbangan psikologi dan pertimbangan sosial sebanyak 40,7\% menjawab sangat setuju, setuju sebanyak \% dan kurang setuju sebanyak 59,3\%.

3. Jawaban responden mengenai umumnya keempat pertimbangan tersebut selalu menjadi perhatian pegawai sebanyak $20,4 \%$ menjawab sangat setuju, setuju sebanyak $64,8 \%$ dan kurang setuju sebanyak $14,8 \%$.

4. Jawaban responden mengenai efektivitas kerja adalah penyelesaian pekerjaan tepat pada waktu yang telah ditentukan, artinya pelaksanaan suatu tugas ditandai baik atau tidak, sangat tergantung pada penyelesaian tugas sebanyak $35,2 \%$ menjawab sangat setuju, setuju sebanyak $64,8 \%$.

5. Jawaban responden mengenai efektivits dapat dilihat dari dua sisi perbandingan yakni segi usaha dan segi hasil sebanyak 35,2\% menjawab sangat setuju, setuju sebanyak $63,0 \%$ dan kurang setuju sebanyak $1,9 \%$.

6. Jawaban responden mengenai suatu kegiatan dapat dikatakan efisien kalau sesuatu hasil tertentu tercapai dengan usaha yang sekecil-kecilnya sebanyak 1,9\% menjawab sangat setuju, setuju sebanyak 70,4\% dan kurang setuju sebanyak $27,8 \%$.

7. Jawaban responden mengenaisuatu kegiatan dapat disebut efektif kalau dengan sesuatu usaha tertentu memberikan hasil yang sebanyak-banyaknya sebanyak $1,9 \%$ menjawab sangat setuju, setuju sebanyak $57,4 \%$ dankurang setuju sebanyak $40,7 \%$.

8. Jawaban responden mengenai efektivitas kerja diukur dari produktivitas kerja pegawai setuju sebanyak $77,8 \%$ dan kurang setuju sebanyak $22,2 \%$.

9. Jawaban responden mengenai faktor-faktor yang mempengaruhi produktivitas antara lain adalah : kecakapan pegawai/pekerja, kreativitas, hasil kerja yang bermutu, disiplin kerja sebanyak 68,5\% menjawab setuju, kurang setuju sebanyak 29,6\% dan tidak setuju sebanyak $1,9 \%$.

10. Jawaban responden mengenai pribadi yang produktif menggambarkan potensi, persepsi dan kreativitas seseorang sebanyak 53,7\% menjawab setuju dan kurang setuju sebanyak $46,3 \%$.

11. Jawaban responden mengenaiperlunya interaksi dalam budaya organisasi sebanyak $20,4 \%$ menjawab sangat setuju, setuju sebanyak $74,1 \%$ dan kurang setuju sebanyak $5,6 \%$.

12. Jawaban responden mengenai budaya organisasi mengarahkan perilaku anggota organisasi sesuai budaya yang ada sebanyak $16,7 \%$ menjawab sangat setuju, setuju sebanyak $64,8 \%$, kurang setuju sebanyak $14,8 \%$ dan tidak setuju sebanyak $3,7 \%$. 
13. Jawaban responden mengenai budaya organisasi berfungsi memberikan sense of identity kepada para anggota sebanyak 46,3\% menjawab sangat setuju, setuju sebanyak $53,7 \%$.

14. Jawaban responden mengenai budaya organisasi juga berfungsi memberikan arah dan memperkuat standar perilaku pegawai sebanyak 46,3\% menjawab sangat setuju, setuju sebanyak $53,7 \%$.

15. Jawaban responden mengenai fungsi lain dari budaya organisasi adalah membantu dan mendesain kembali sistem pengendalian manajemen sebanyak 50,0\% menjawab sangat setuju, setuju sebanyak $50,0 \%$.

16. Jawaban responden mengenai ada hubungan budaya organisasi dengan efektivitas organisasi sebanyak $9,3 \%$ menjawab sangat setuju, setuju sebanyak $61,1 \%$ dan kurang setuju sebanyak $29,6 \%$.

17. Jawaban responden mengenai otonomi individual perlu untuk memikul tanggung jawab yang lebih besar sebanyak 9,3\% menjawab sangat setuju, setuju sebanyak $51,9 \%$, kurang setuju sebanyak 33,3\%, tidak setuju sebanyak $3,7 \%$ dan sangat tidak setuju sebanyak $1,9 \%$.

18. Jawaban responden mengenai peluang untuk berprakarsa adalah ciri budaya organisasi sebanyak 9,3\% menjawab sangat setuju, setuju sebanyak 55,6\%, kurang setuju sebanyak $31,5 \%$ dan tidak setuju sebanyak $3,7 \%$.

19. Jawaban responden mengenai ciri lain budaya organisasi adalah struktur organisasi yang mencerminkan berbagai ketentuan formal dan normatif sebanyak 5,6\% menjawab sangat setuju, setuju sebanyak 50,0\% dan kurang setuju sebanyak 44,4\%.

20. Jawaban responden mengenai budaya organisasi terbentuk melalui interaksi antara perilaku pegawai yang dipengaruhi oleh nilai-nilai, kepercayaan dan sikap yang melekat pada individu dipadukan dengan kultur korporat yang ideal yang diinginkan oleh organisasi sebanyak 9,3\% menjawab sangat setuju, setuju sebanyak 57,4\%, kurang setuju sebanyak $31,5 \%$ dan tidak setuju sebanyak $1,9 \%$.

\section{Uji Kualitas Data}

\section{Validitas}

Pengujian validitas instrumen dapat dilihat pada kolom Corrected Item-Total Correlation. Jika angka korelasi yang diperoleh lebih besar dari pada angka kritik (r-hitung > r-tabel) maka instrumen tersebut dikatakan valid. Berdasarkan uji validitas dapat disimpulkan bahwa seluruh item pertanyaan untuk mengukur masing-masing variabel penelitian dinyatakan valid.

\section{Reliabilitas}

Setelah melakukan uji validitas, langkah selanjutnya adalah melakukan uji reliabilitas data untuk mengetahui apakah instrumen tersebut telah reliabel dengan melihat nilai Cronbach's Alpha. Uji reliabilitas dilakukan untuk mengetahui apakah alat pengukur yang digunakan dapat diandalkan dan tetap konsisten jika pengukuran tersebut diulang. Suatu kuesioner dikatakan reliabel jika Cronbach's Alpha lebih besar dari 0,6. Hal ini menunjukkan bahwa data penelitian dinyatakan reliabel. Hasil perhitungan uji reliabilitas 
menunjukkan alpha cronbach's pada masing-masing kolom variabel tersebut lebih besar dari 0,6 (batas reliabilitas) maka dapat dinyatakan instrumen tersebut reliabel.

\section{Uji Asumsi Klasik}

\section{Uji Normalitas}

Dari uji normalitas dapat dilihat bahwa data menyebar disekitar garis diagonal dan mengikuti arah garis diagonal pada grafik histogram, hal ini menunjukkan bahwa pola distribusi normal. Jadi dapat disimpulkan bahwa berdasarkan grafik P-P plot, model regresi memenuhi asumsi normalitas.

\section{Uji Multikolinieritas}

Melihat hasil besaran nilai tolerance menunjukkan tidak ada variabel independen yang memiliki nilai tolerance kurang dari 0.10 yang berarti tidak ada korelasi antar variabel independen atau tidak terjadi multikolinieritas. Hasil perhitungan nilai variance inflation factor (VIF) juga menunjukkan hal yang sama tidak ada satu variabel independen yang memiliki nilai VIF lebih dari 10. jadi dapat disimpulkan bahwa tidak ada multikolinieritas antar variabel independen dalam model regresi.

\section{Uji Heteroskedastisitas}

Pengujian asumsi heteroskedastisitas menyimpulkan bahwa model regresi tidak terjadi heteroskedastisitas. Dengan kata lain terjadi kesamaan varian dari residual dari satu pengamatan ke pengamatan yang lain.

\section{Pengujian Hipotesis}

Untuk menguji hipotesis mengenai pengaruh budaya organisasi, gaya kepemimpinan dan komitmen pegawaiterhadap kinerja pegawai secara simultan dan parsial digunakan pengujian hipotesis secara simultan dengan uji $\mathrm{F}$ dan secara parsial dengan uji t.

\section{Pengujian Hipotesis dengan Uji $t$}

Pengujian hipotesis dengan uji t, yaitu dengan memperhatikan nilai t hitung dari hasil regresi tersebut untuk mengetahui pengaruh variabel independen secara parsial terhadap variabel dependen dengan tingkat signifikansi dalam penelitian ini menggunakan alpha $5 \%$ atau 0,05. Nilai dari uji t hitung dapat dilihat dari p-value (pada kolom Sig.) pada masingmasing variabel independen, jika p-value lebih kecil dari level of significant yang ditentukan atau t hitung (pada kolom $\mathrm{t}$ ) lebih besar dari t tabel (dihitung dari two-tailed $\alpha=5 \% \mathrm{df}-\mathrm{k}, \mathrm{k}$ merupakan jumlah variabel independen), maka nilai variabel independen secara parsial berpengaruh signifikan terhadap variabel dependen (dalam arti Ha diterima dan Ho ditolak, dengan kata lain, terdapat pengaruh antara variabel independen terhadap variabel dependen).

Adapun metode dalam penentuan $t$ tabel menggunakan ketentuan tingkat signifikan 5 $\%$, dengan $\mathrm{df}=n-k-1$ (pada penelitian ini $\mathrm{df}=54-4-1=49$ ), sehingga didapat nilai $t$ tabel sebesar 2,009.

\section{Pengujian Hipotesis dengan Uji F}

Hasil uji $\mathrm{F}$ menunjukan variabel independen secara bersama-sama berpengaruh terhadap variabel dependen, jika $p$-value (pada kolom sig.) lebih kecil dari level of significant yang ditentukan (sebesar $5 \%$ ), atau F hitung (pada kolom F) lebih besar dari F tabel. F tabel dihitung dengan cara df $1=\mathrm{k}-1$, dan df $2=\mathrm{n}-\mathrm{k}$, yaitu df $1=4-1=3$ dan df2= 54-4=50, 
sehingga didapat nilai $\mathrm{F}$ tabel sebesar 2,79. Sedangkan hasil uji $\mathrm{F}$ dengan bantuan program SPSS.

\section{Analisis Koefisien Determinasi $\left(\boldsymbol{R}^{2}\right)$}

Hasil olahan pada tabel di atas terlihat nilai koefisien determinasi $\left(R^{2}\right)$ yang sudah disesuaikan (Adjusted $R \quad$ Square) sebesar 0,432. Artinya 43,2\% variabel dependen (efektivitas kerja pegawai) dipengaruhi atau dijelaskan oleh variabel independen yaitubudaya organisasi, gaya kepemimpinan, komitmen pegawai dan sisanya sebesar 56,8\% (100\%$43,2 \%$ ) dipengaruhi atau dijelaskan oleh variabel lain di luar variabel yang digunakan dalam penelitian ini.

\section{Hasil Persamaan Regresi}

Pada model regresi ini, nilai konstanta yang tercantum sebesar 18,683dapat diartikan jika variabel bebas dalam model diasumsikan sama dengan nol atau variabel bebas dalam hal inibudaya organisasi, gaya kepemimpinan, komitmen pegawaiditerapkan, maka efektivitas kerja pegawai akan mengalami kenaikan sebesar 18,683 satuan. Nilai besaran koefisien regresi $\beta_{1}$ sebesar 0,349 pada penelitian ini dapat diartikan bahwa variabel budaya organisasi(X1) berpengaruh terhadap efektivitas kerja pegawai (Y). Hal ini menunjukkan bahwa ketika budaya organisasiterpenuhi, maka efektivitas kerja pegawaiakan naik 0,349 satuan.

\section{KESIMPULAN}

Sesuai dengan hasil analisis data maka ditemukan bahwa Budaya organisasi berpengaruh positif dan signifikan terhadap kinerja pegawai Kantor Pelayanan Pajak Pratama Medan Kota, hal ini didukung hasilanalisisthitung $>$ t-tabel $(3,603>2,009)$ pada $n=54$ pada taraf sifgifikansi $95 \%$.

\section{DAFTAR PUSTAKA}

Koesmono, Teman H. 2009. Pengaruh Budaya Organisasi Terhadap Motivasi dan Kepuasan Kerja Serta Kinerja Karyawan Pada Sub Sektor Industri Pengolahan Kayu Skala Menengah Di Jawa Timur. Jurnal Manajemen \& Kewirausahaan, Vol. 7 No. 2

Komaruddin. 2007. Ensiklopedia Manajemen, Alumni Bandung

Lok, Peter dan Crawford, John. 2008. The Effect of Organizational Culture and Leadership Style on Job Satisfaction and Organizational Commitment. The Journal of Management Development, Vol. 23 No. 4

Sarwoto. 2008. Organisasi dan Manajemen. Ghalia Indonesia, Jakarta.

Schein, E. 2008. Organizational Culture and Leadership, 2nd Ed. Jossey-Bass Publishers San Fransisco.

Sharplin. 2009. Strategic Management, Mc. Graw-Hill, New York 
